\title{
TEACHING FOREIGN LANGUAGES AT THE UNIVERSITY OF ECONOMICS IN BRATISLAVA IN CONNECTION TO THE NEEDS OF THE LABOUR MARKET
}

\author{
Michaela Čiefová \\ University of Economics in Bratislava, Slovak Republic \\ michaela.ciefova@euba.sk \\ Katarína Seresová \\ University of Economics in Bratislava, Slovak Republic \\ katarina.seresova@euba.sk
}

\begin{abstract}
The objective of the authors of the article was to analyse the labour market from the point of view of languages used by individual foreign companies in Slovakia. Since insufficient language competence of employees is one of the causes of youth unemployment in the European Union, the paper focuses also on language preparation of the students at the University of Economics in Bratislava, and contemplates the fact whether real foreign language knowledge of the graduates meets the requirements of the labour market, and whether the curricula of individual subjects reflect these requirements. English was proven to be the most frequently selected foreign language by the students, followed by German. Since there are many American, British, as well as German and Austrian companies located in Bratislava, we find this situation rather positive. However, we highly recommend students to acquire at least basic knowledge of German in order to increase their competitive advantage.
\end{abstract}

Keywords: University of Economics in Bratislava; foreign language teaching; labour market; international companies; youth unemployment

\section{Introduction}

The University of Economics in Bratislava (hereinafter referred to as "UEBA") belongs to the topranked providers of higher education in the Slovak Republic with its history dating back to 1940. Throughout its existence, the structure and the name of the institution had been amended several times, until the adoption of the Act no. 292/1992 Coll., when the actual name was adopted (Slov-Lex, 2017). Currently, it is composed of 7 faculties, 6 of them located in Bratislava (Faculty of National Economy, Faculty of Commerce, Faculty of Economic Informatics, Faculty of Business Management, Faculty of International Relations and Faculty of Applied Languages), 1 with its premises located in Košice (Faculty of Business Economy). From its foundation on, more than 80 thousand students have successfully graduated from this institution. Approximately 12 thousand students are currently studying various economics-related disciplines at the UEBA (University of Economics in Bratislava, 2017).

Apart from knowledge of economics and related disciplines, each graduate from the UEBA is supposed to possess communicative competence in at least two foreign languages, which is also in line with the intention of the European Union regarding language competence of its citizens.

The main objective of this paper is to analyse teaching foreign languages at the University of Economics in Bratislava in connection to the language-related requirements of the labour market, predominantly from the point of view of foreign enterprises and their requirements regarding language competence of their employees.

The primary research objective is to analyse whether the foreign language teaching at the UEBA is sufficient enough to meet the requirements of the labour market, predominantly in Bratislava and surrounding areas. We attempt to provide the answer on the question whether graduates from the UEBA dispose of language competence equivalent to the requirements of their potential employers. Based on the research results, possible improvements measures will be proposed whose implementation might help to cover potential niches. Such measures may repose in increasing the number of teaching hours or seminars for the languages requiring more attention. The largest international companies in Bratislava will be discussed with regards to their corporate language. The result of this analysis will be confronted with the language learning opportunities for students of the UEBA. The research is based on an assumption that creators of learning programmes at the UEBA take the situation and developments on the labour market into account when deciding on the content of study plans.

A fact is that the unemployment of young people (regarding youth unemployment, usually people aged 15 - 24 years are referred to) represents a serious problem for the European Union (Harakal'ová, 2016, p. 164). This may be, besides others, due to foreign language competence being insufficient to meet requirements of the labour market. 


\section{Methodology}

The present research is based on the analysis of languages offered by the UEBA to students as part of the curricula, and thus from the quantitative point of view. Concrete numerical data provided by the Faculty of Applied Languages reflecting numbers of students enrolled for particular foreign languages is analysed. On the grounds of this, the languages are organised according to the students' preferences. Data from the academic year 2013/2014 is used, since data from further academic years has not been processed. Therefore, we assume that the current state would be very similar.

Next, the largest companies in Bratislava and the whole region are analysed. Special attention is paid predominantly to companies' countries of origin, or countries, where the companies have their headquarters. Although English is generally required by almost every employer, we suppose that in each company also the language of its home country is, at least for some job positions, necessary. For the purpose of the research, we consider the language of the country of origin to be the corporate language, which is likely to be required by the hiring managers. This helps us to evaluate, what languages are most frequently sought by applicants.

Consequently, an analysis of the languages that are taught at the university and those which are required by employers will enable us to conclude, whether foreign language teaching at the UEBA meets the needs of the labour market, or whether certain improvement measures could be proposed.

\section{Foreign language competence in the European Union}

With regards to European language policy, one of the primary objectives of the European Union is to strengthen language competence of its citizens. More exactly, every citizen of EU-member states is supposed to master at least 2 foreign languages. This should be executed by means of language learning, which is funded by various programmes and projects. The reason behind the EU's interest in language learning support is the idea of languages being a significant part of European identity as well as an explicit expression of a culture. Linguistic diversity in Europe is therefore considered to be a key phenomenon. Furthermore, language competence is thought to be one of the skills improving opportunities on the labour market (European Parliament, 2016).

The idea of mastering at least 2 foreign languages emerged in 2002. The report points at the need "to improve the mastery of basic skills, in particular by teaching at least two foreign languages from a very early age: establishment of a linguistic competence indicator in 2003..."(Barcelona European Council, 2002, p. 19).

According to the Statistical Office of the European Union, foreign language competence among its citizens, citizens of Slovakia and its neighbouring countries (apart from Ukraine, since Ukraine as a nonmember state was not included in the research) aged 25-64 was 2011 as demonstrated in the Figure 1 (\%) (Eurostat, 2015).

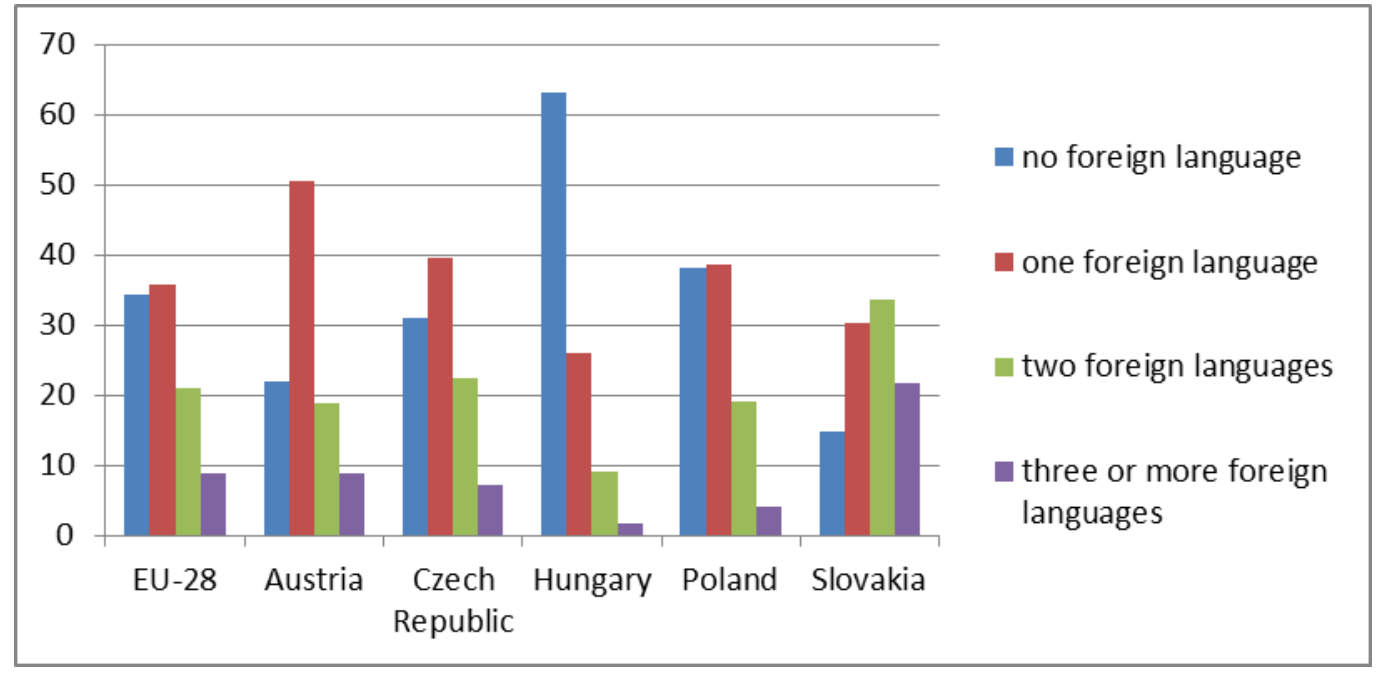

Figure 1.Foreign language competence in chosen EU-countries

Source: Own processing according to Eurostat

It is important to mention that foreign language competence is considered to be a success factor in the international workspace. In Bratislava, which is not only the capital of Slovakia but a political, economic and business centre of the Republic and one of the richest regions in the European Union with a variety of multinational corporations, the ability to communicate in a foreign language is a necessity. Comparing the situation in Slovakia in 2011, when $14.70 \%$ of people claimed not to speak any foreign language, with its 
neighbouring countries, the outcome is a relatively positive finding in favour of Slovakia. Furthermore, it was deeply under the EU-28 average, which amounted to $34.30 \%$. Besides that, the data indicate an interesting trend, as even $21.60 \%$ Slovaks reported themselves as knowing 3 or more languages. This also differs significantly from the EU-28 average (8.80\%) (Figure 1).

For the purpose of this paper, we suppose that foreign language competence of the young generation (up to the age of 24) might be on a very similar level.

\section{Youth unemployment as a negative trend in Europe}

As already mentioned, unemployment of young generation represents a crucial problem in the European Union, especially in Spain, Greece, Croatia, Italy, Portugal and Cyprus. The youth unemployment rate has been declining since 2013, although not in every country. Despite the decline in unemployment of young people, the rate remains on a high level. One of the consequences of this development is a significant difference among countries (Harakal'ová, 2016, p. 165).

In the context of the major European Union proposals, the strategy "Europe 2020", the initiative from this framework "Youth on the move" should be mentioned, since it concerns education and employment of young people. The objective of tackling the unemployment of the young generation is closely linked to the more general aim of the European Union consisting in the achievement of $75 \%$ employment rate in working population (persons aged 20-64 years) (Harakal'ová, Lipková, Grešš, 2015, p. 320). In addition, not only unemployment, but also social exclusion is a problem the European Union needs to face and is aware of (Šoltés, Šoltésová, Hrivíková, 2016, p. 1692).

Despite the fact that the youth unemployment rate in Slovakia is still on a relatively high level, we can see a positive trend because of decline in numerical data. In 2013, the youth unemployment rate in Slovakia constituted $33.70 \%$; in 2014, it was reduced to $29.70 \%$, and further declining. In 2015, it was already $26.50 \%$ (Eurostat, 2017). Only throughout the year 2016, the youth unemployment rate in Slovakia lowered from $24.8 \%$ in January to $20.4 \%$ in December. The fall thus represents approximately $4.4 \%$ (Trading Economics / Eurostat, 2017). According to the Trading Economics forecast, the youth unemployment rate in Slovakia will continue to decline, reaching $17.58 \%$ in 2020. The last prediction comes from 24 February 2017.

The development on the EU-wide level is different from Slovak trends. Throughout 2016, the data was fluctuating between 18,5\% and 19,3\%. (Trading Economics / Eurostat, 2017). The difference between the youth unemployment rate at the beginning and the end of the year was thus less significant than in Slovakia. Although the youth unemployment rate in the European Union as a whole was not only declining, but even increasing or stagnating, the nominal rate was lower than that in Slovakia (Figure 2).

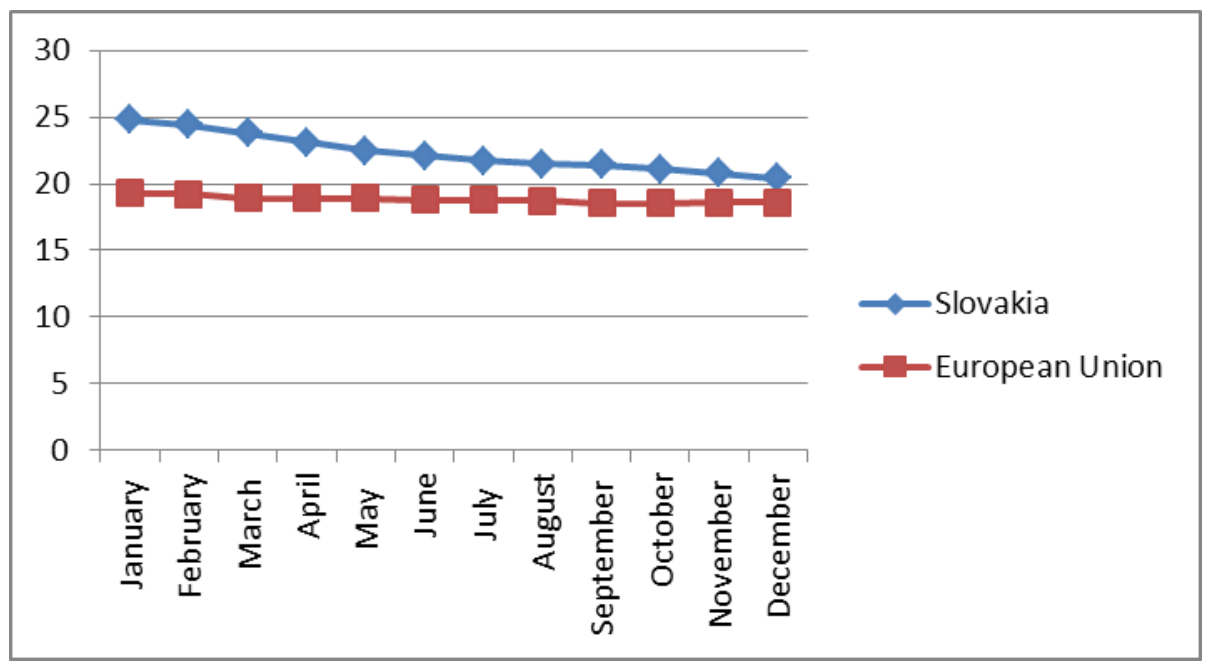

Figure 2. Development of youth unemployment in Slovakia and the EU in 2016

Source: Own processing according to Trading Economics / Eurostat

The analysed data proves the fact that the unemployment of young generation is a problem that needs to be dealt with. Youth unemployment may in some cases result in a long-term unemployment (Bugárová, 2016, p. 22). When talking specifically about the unemployment of graduates, Slovakia belongs to the EUcountries with the highest level of unemployed graduates (Bugárová, 2016, p. 28). The reason for this trend may be, apart from other factors, insufficient foreign language competence. The chance to succeed in the labour market can then be relatively low. We, therefore, agree with the objective of the European Union and 
believe, it is necessary to acquire foreign language competence corresponding to the needs of the labour market. Without language skills, it may nowadays be a serious problem to find employment meeting one's needs and requirements.

Language skills can be considered a component of one's qualification. The research by Lučkaničová, Ondrušeková and Rešovský (2012) depicts a marked trend for employers in Slovakia to prefer educated young people with prospects, while at the same time require a high level of qualification and relevant experience (p. 35).

Moreover, also young people's preferences regarding their potential employer have been undergoing some changes. Grencikova, Spankova and Karbach (2015) describe this tendency as follows: "Young people do not want to have a fixed, single career, instead, they are going to work for multiple employers and be independent" (p. 294).

\section{Foreign languages taught at the University of Economics in Bratislava}

Although most of the students attending the UEBA are Slovak citizens with Slovak being their mother tongue, and also majority of the learning programmes taught at the UEBA is conducted in Slovak, there are also programmes offered in a foreign language, such as International Financial Management (Internationales Finanzmanagement) in German, Sales Management (Managment de la Vente) in French and General Management and International Finance in English. Apart from that, there is also a learning programme in Foreign Languages and Intercultural Communication at the Faculty of Applied Languages taught in English or German (University of Economics in Bratislava, 2017). As far as the structure of Slovak learning programmes is concerned, each of them also contains a foreign language unit.

Students of the UEBA can choose one of the following foreign languages: English, German, Spanish, French, Russian and Italian, and even Slovak for those having a different mother tongue. If needed, a Chinese or Arabic language class can be opened. In the academic year 2013/2014 the share of languages based on the number of students was as shown in Table 1 (the abbreviation FT stands for full-time; PT for part-time):

Table 1

Foreign languages taught at the University of Economics in Bratislava in the academic year 2013/2014 and respective numbers of students

\begin{tabular}{|c|c|c|c|c|c|c|c|c|}
\hline \multicolumn{4}{|c|}{ Summer semester 2013/2014 } & \multicolumn{3}{c|}{ Winter semester 2013/2014 } \\
\hline language & $\begin{array}{c}\text { FT } \\
\text { enrolled }\end{array}$ & $\begin{array}{c}\text { FT } \\
\text { active }\end{array}$ & $\begin{array}{c}\text { PT } \\
\text { enrolled }\end{array}$ & $\begin{array}{c}\text { PT } \\
\text { active }\end{array}$ & $\begin{array}{c}\text { FT } \\
\text { enrolled }\end{array}$ & $\begin{array}{c}\text { FT } \\
\text { active }\end{array}$ & $\begin{array}{c}\text { PT } \\
\text { enrolled }\end{array}$ & $\begin{array}{c}\text { PT } \\
\text { active }\end{array}$ \\
\hline English & 1868 & 1484 & 391 & 156 & 2453 & 1923 & 322 & 202 \\
\hline German & 1586 & 1245 & 205 & 124 & 1011 & 843 & 186 & 100 \\
\hline Spanish & 718 & 541 & 38 & 22 & 568 & 417 & 21 & 10 \\
\hline French & 631 & 497 & 28 & 18 & 498 & 386 & 21 & 12 \\
\hline Russian & 507 & 398 & 23 & 17 & 418 & 323 & 16 & 13 \\
\hline Italian & 115 & 86 & 6 & 3 & 82 & 63 & 4 & 2 \\
\hline Slovak & 25 & 24 & 1 & 0 & 39 & 36 & 0 & 0 \\
\hline TOTAL & $\mathbf{5 4 5 0}$ & $\mathbf{4 2 7 5}$ & $\mathbf{6 9 2}$ & $\mathbf{3 4 0}$ & $\mathbf{5 0 6 9}$ & $\mathbf{3 9 9 1}$ & $\mathbf{5 7 0}$ & $\mathbf{3 3 9}$ \\
\hline
\end{tabular}

Source: Data provided by the Faculty of Applied Languages

It is obvious that the English language has the highest representation among students and is followed by German. The third most taught foreign language was Spanish, followed by French, Russian and Italian. The lowest number of students chose Slovak as a foreign language. Those are mostly exchange students.

Taking exclusively the active students into account, the percentage calculations of the individual languages would be as follows: $34.71 \%$ of full-time students and $45.88 \%$ of part-time students learnt English in the summer semester of the academic year 2013/2014. During the same semester 29.12\% of full-time and $36.47 \%$ of part-time students chose German as a foreign language. In the winter semester, the numbers were slightly different, and thus $48.18 \%$ of full-time and $59.59 \%$ of part-time students attended an English course while $21.12 \%$ of full-time and $29.50 \%$ of part-time students attended a German language course. Representation of other languages was much less significant.

As far as following academic years are concerned, we suppose very similar data would have been obtained also in the academic years 2014/2015, 2015/2016 and the current one. However, the exact numerical data is not at our disposal because it has not been processed. The data presented above will thus be considered to mirror the current situation as well. 


\section{The largest companies in Bratislava as potential employers of the UEBA graduates}

We assume that English is most likely to be required at recruitment processes into international corporations in Bratislava. In the following part, the largest companies in Bratislava region will be confronted with their corporate languages. In this context, we consider a corporate language to be the language of the country where the company has its headquarters, or the country of origin. For the purpose of this paper, these corporations are viewed as potential employers. Our analysis is based on data from 2015, because relevant data from 2016 has not been published yet. The main criterion of companies' ranking is their revenue and the region - Bratislava. The data in Table 2 comes from the database of financial data (FinStat, 2017).

Table 2

The largest companies in the region of Bratislava based on revenue

\begin{tabular}{|c|c|c|c|}
\hline Company's business name & Business activity & Ownership & $\begin{array}{l}\text { Country of origin / } \\
\text { shareholders / } \\
\text { directory }\end{array}$ \\
\hline $\begin{array}{l}\text { 1. VOLKSWAGEN } \\
\text { SLOVAKIA, a.s. }\end{array}$ & Automotive industry & Foreign & Germany \\
\hline 2. $\quad$ SLOVNAFT, a.s. & $\begin{array}{l}\text { Chemistry and } \\
\text { plastics }\end{array}$ & $\begin{array}{l}\text { International with } \\
\text { prevailing private } \\
\text { sector }\end{array}$ & Slovakia, Hungary \\
\hline $\begin{array}{l}\text { 3. Všeobecná zdravotná } \\
\text { poist'ovňa, a.s. }\end{array}$ & Finance & State & Slovakia \\
\hline 4. Slovenské elektrárne, a.s. & $\begin{array}{l}\text { Energy and } \\
\text { extraction }\end{array}$ & $\begin{array}{l}\text { International with } \\
\text { prevailing private } \\
\text { sector }\end{array}$ & Slovakia \\
\hline 5. TESCO STORES SR, a.s. & Retail & Foreign & United Kingdom \\
\hline $\begin{array}{l}\text { 6. Slovenský plynárenský } \\
\text { priemysel, a.s. }\end{array}$ & $\begin{array}{l}\text { Energy and } \\
\text { extraction }\end{array}$ & State & Slovakia \\
\hline $\begin{array}{l}\text { 7. DOVERA zdravotná } \\
\text { poist'ovňa, a.s. }\end{array}$ & Finance & Foreign & The Netherlands \\
\hline 8. $\quad$ OKTE, a.s. & Procurement & Private domestic & Slovakia \\
\hline $\begin{array}{l}\text { 9. Lidl SLovenská republika, } \\
\text { v.o.s. }\end{array}$ & Retail & $\begin{array}{l}\text { International with } \\
\text { prevailing private } \\
\text { sector }\end{array}$ & Germany \\
\hline $\begin{array}{l}\text { 10. Kaufland Slovenská } \\
\text { republika, v.o.s. }\end{array}$ & Retail & $\begin{array}{l}\text { International with } \\
\text { prevailing private } \\
\text { sector }\end{array}$ & Germany \\
\hline $\begin{array}{l}\text { 11. Tesco International } \\
\text { Clothing Brand s.r.o. }\end{array}$ & $\begin{array}{l}\text { Transport and } \\
\text { logistics }\end{array}$ & $\begin{array}{l}\text { International with } \\
\text { prevailing private } \\
\text { sector }\end{array}$ & $\begin{array}{l}\text { United Kingdom / } \\
\text { the Netherlands }\end{array}$ \\
\hline 12. ZSE Energia, a.s. & $\begin{array}{l}\text { Energy and } \\
\text { extraction }\end{array}$ & Private domestic & Slovakia \\
\hline 13. Eustream, a.s. & $\begin{array}{l}\text { Transport and } \\
\text { logistics }\end{array}$ & Private domestic & Slovakia \\
\hline 14. $\quad$ Slovak Telekom, a.s. & Telecommunication & Foreign & Germany \\
\hline $\begin{array}{l}\text { 15. } \\
\text { JOHNSON CONTROLS } \\
\text { INTERNATIONAL, spol. s.r.o. }\end{array}$ & Automotive industry & Foreign & USA \\
\hline 16. $\quad$ OMV Slovensko, s.r.o. & Wholesale & Foreign & Austria \\
\hline 17. SAS Automotive s.r.o. & Automotive industry & Foreign & Germany \\
\hline
\end{tabular}

Source: Own processing according to the web site of Financial data database

When analysing the largest companies in Bratislava region, we need to mention that, besides foreign companies, several Slovak state-owned enterprises belong to those with the highest revenue. British and American corporations also play a very important role. Among others, German companies hold an important position on the market as well. It is to be mentioned that these companies not only demonstrate the highest revenues, but are also employ the largest number of workers in Slovakia. Therefore, as already mentioned, they are likely to become employers of graduates from the UEBA. 
Despite the fact that German is the second most often studied foreign language at the UEBA, we would highly recommend students to acquire at least basic knowledge of this language, since the amount of German and Austrian companies in the region indicates a need of being able to communicate in German. Due to the presence of not only German but also Austrian firms in Bratislava and surrounding areas, it is a great advantage to be capable of active communication in German. Knowledge of the German language may considerably increase one's chances on the labour market. In combination with English, it is virtually a success factor.

Adamcová sums up the reasons for learning and using German in Slovakia as follows: Germany, Austria and Switzerland are the most important business partners of Slovakia; media from German-speaking countries are popular here, as well. Besides that, intercultural encounters between Slovakia and Germany have been occurring for a very long period of time, therefore it is not possible to imagine Slovak history without German presence (Adamcová, 2010, p. 41). We can also mention the geographical aspect, i.e. the proximity of Slovakia and the German-speaking countries in question.

We find it necessary to mention that the UEBA has entered into bilateral agreements with dozens of foreign universities and providers of higher education (e.g. within the Erasmus+ programme). The students may therefore choose from a variety of institution from all around Europe and thus improve their language competence.

\section{Conclusion}

The main intention of this paper was to analyse foreign languages being taught at the University of Economics in Bratislava in view of the labour market requirements. The primary research question was whether teaching foreign languages at this institution is efficient enough to prepare its students for a professional career, i.e. whether a graduate possesses language competences required by companies operating on the labour market in the region.

One of the main findings of our study was the dominance of English as a taught subject at the UEBA. However, such a result was even presupposed prior to the analysis initiation. The second most frequently foreign language chosen by the students was German, followed by Spanish and French. Next, we elaborated a list of the largest companies in Bratislava, and thus with regards to their revenues. Some of them are owned by the state; some of them also belong to the largest companies as far as the number of employees is concerned.

Out of the stated companies, approximately every third one is a German or an Austrian corporation. We suppose that the English language is required by most of the companies in the ranking, or it depends on the vacancy, respectively. Since it was proved that also German and Austrian companies belonged to the most significant ones, we would recommend students to attempt to acquire at least basic knowledge of German, besides other languages, as in Bratislava and the whole region it might be really advantageous. One way to do it is to apply for a mobility programme abroad, since the UEBA offers its students a number of opportunities to study in a foreign country. Many of them are under the auspices of the European Union, whose target is to support foreign language of its citizens.

On the other hand, the finding that German is the second most frequently taught language at the UEBA corresponds to the amount of companies from German speaking countries doing business in Bratislava. Therefore, we may conclude that the University takes into consideration the developments and trends on the labour market when elaborating the study curricula. Besides that, also students are likely to be aware of the added value, which German language brings.

The same methodology might be used also in the future to analyse foreign language competence and labour market requirements in other regions, or to analyse foreign language teaching at other universities and providers of higher education. We believe that situation on the labour market regarding required languages is always to be taken into consideration by those preparing study plans at various universities.

\section{References:}

Adamcová, L. (2010). Ausgewählte Forschungsschwerpunkte der germanistischen Linguistik in der Gegenwart [Chosen research focuses of contemporary Germanic linguistics]. Bratislava: Sprint dva.

Barcelona European Council (15 and 16 March, 2002). Presidency conclusions. Retrieved February 15, 2017, from http://www.consi lium.europa.eu/uedocs/cms_data/docs/pressdata/en/ec/71025.pdf

Bugárová, M. (2016). Rizikové skupiny na trhu práce s dôrazom na absolventov škôl [Risk groups in the labour market with an emphasis on graduates]. Revue sociálno-ekonomického rozvoja, 2, 22-33.

European Parliament (2016). Language policy. Retrieved February 10, 2017, from http://www.europarl.europa.eu/atyourservice/en/di splayFtu.html?ftuId=FTU_5.13.6.html

Eurostat (2015). Number of foreign languages known (self-reported) by age. Retrieved February 05, 2017, from http://appsso.eurostat.ec.europa.eu/nui/show.do?dataset=edat_aes_122\&lang=en

Eurostat (2017). Youth unemployment figures. Retrieved February 24, 2017, from http://ec.europa.eu/eurostat/statisticsexplained/images/f/f4/Youth_unemployment_figures\%2C_2012-2015Q4_\%28\%25\%29_T1.png 
Faculty of Applied Languages (2017) - data regarding numbers of students attending foreign language courses.

FinStat. (2017). Databáza finančných údajov - hospodárske výsledky firiem [Financial data database - companies' economic results]. Retrieved February 20, 2017, from http://www.finstat.sk/databaza-financnychudajov? Activity=\&Region=bratislavsk\%C3\%BD\&Sales=\&Years=2015\&Employee=\&PerPage=20\&Sort=sales-desc \&Tab=

Grencikova, A. Spankova, J. \& Karbach, R. (2015). Current trends in enterprise employment policies in Slovak Republic. Actual problems of economics, 8 (170), 293-301.

Harakal'ová, L. (2016). Nezamestnanost' mladých - sú riešenia Európskej únie účinné? [Youth unemployment. Are the EU's solutions effective?]. Ekonomické, politické a právne otázky medzinárodných vztahov 2016 - Zborník vedeckých prác, pp. 164-171.

Harakal'ová, L'., Lipková, L., \& Grešš, M. (2015). Education policy of the European Union and its reflection in the strategy "Europe 2020". Actual problems of economics, 8 (170), 318-326.

Lučkaničová, M., Ondrušeková, I., \& Rešovský, M. (2012). Employment modeling in Slovakia: Comparing logit models in 2005 and 2009. Economic Annals, 57 (192), 25-39. https://doi.org/10.2298/eka12920251.

Slov-Lex (2017). Právny a informačný portál [Legal and information portal]. Retrieved February 10, 2017, from https://www.slovlex.sk/pravne-predpisy/SK/ZZ/1992/292/19920701

Šoltés, E., Šoltésová, T., \& Hrivíková, T. (2016). Spacial Analysis of Income Poverty and Social Exclusion in European Union - 28 in 2014. Journal of applied economic sciences, 11 (46), 1692-1707.

Trading Economics (2017). Slovakia Youth Unemployment Rate. Retrieved February 24, 2017, from http://www.tradingeconomics.com/ slovakia/youth-unemployment-rate

Trading Economics (2017). Slovakia Youth Unemployment Rate - Forecast 2016-2020. Retrieved February 24, 2017, from http://www.tradingeconomics.com/slovakia/youth-unemployment-rate/forecast

Trading Economics (2017). European Union Youth Unemployment Rate. Retrieved February 24, 2017, from http://www.trading economics.com/european-union/youth-unemployment-rate

University of Economics in Bratislava (2017). Degree Programmes Taught in Foreign Language. Retrieved February 10, 2017, from $\mathrm{http} / / / \mathrm{www}$.euba.sk/students/degree-programmes-taught-in-foreign-language

University of Economics in Bratislava (2017). History. Retrieved February 10, 2017, from http://www.euba.sk/aboutuniversity/history 